\title{
Caucalières et Labruguière
}

Prospections

Jacques Solé et Jacques Nègre

\section{(2) OpenEdition}

Journals

Édition électronique

URL : http://journals.openedition.org/adlfi/10683

ISSN : 2114-0502

Éditeur

Ministère de la culture

Référence électronique

Jacques Solé et Jacques Nègre, «Caucalières et Labruguière ", ADLFI. Archéologie de la France -

Informations [En ligne], Midi-Pyrénées, mis en ligne le 01 mars 1997, consulté le 19 avril 2019. URL

http://journals.openedition.org/adlfi/10683

Ce document a été généré automatiquement le 19 avril 2019

(c) Ministère de la Culture et de la Communication, CNRS 


\title{
Caucalières et Labruguière
}

\author{
Prospections
}

\author{
J Solé et Jacques Nègre
}

Date de l'opération : 1988 - 1989 (PR)

Inventeur(s) : Solé J ; Nègre Jacques

$1 \mathrm{Au}$ cours de prospections systématiques entreprises sur les communes de Caucalières et de Labruguière, deux gisements protohistoriques ont pu être reconnus et correspondent, pour l'un d'entre eux au moins, à l'implantation d'un habitat (?) dans un secteur de la Montagne Noire, qui n'avait jusqu'alors livré aucun indice d'occupation.

2 Dans les deux cas, il s'agit de fragments d'amphores vinaires italiques du I ${ }^{\mathrm{er}} \mathrm{s}$. avant J.-C., recueillis, d'une part, à Caucalières au lieu-dit Pisse-Lièvre et, d'autre part, à Sagne Grande dans la commune de Labruguière.

\section{INDEX}

Index chronologique : Deuxième âge du Fer Index géographique : Midi-Pyrénées, Tarn, Caucalières, Labruguière operation prospection (PR) 